http://dx.doi.org/10.1590/0370-44672018720107

\author{
Abdelaziz Boutrid ${ }^{1,2,3}$ \\ https://orcid.org/0000-0002-1041-3904 \\ Belgacem Mamen ${ }^{1,4}$ \\ Mohamed Cherif Djouama ${ }^{3,5}$ \\ Momhamed Chettibi ${ }^{2,6}$ \\ ${ }^{1}$ Abbés Laghrour University - Faculty of Science \\ and Technology, Department of Civil Engineering \\ Khenchela- Algeria \\ ${ }^{2}$ Mineral Processing and Environmental \\ Laboratory, Department of Mines, Badij Mokhtar \\ University of Annaba. \\ ${ }^{3}$ Badji Mokhtar University, Mining Department- \\ Laboratory of Physical, Metallurgy and Materials \\ Properties, Annaba - Algeria. \\ E-mails: ${ }^{3}$ abdelaziz.boutrid@univ-khenchela.dz, \\ ${ }^{4}$ mamen.belgacem@gmail.com, \\ 5djouamamohamedcherif@yahoo.fr, \\ ${ }^{6}$ chettibi2005@yahoo.fr
}

\title{
Miningo
}

\section{Depth effect on sandstone strength properties}

\begin{abstract}
The present article focuses on the study of different physical-mechanical parameters; it presents the results of a preliminary investigation aimed at experimental characterization.

To simulate the mechanical behavior of the rock, a reference material needs to be chosen. The reference material selected is Sandstone, which is commonly used in this field of study.

The behavior of sandstone from the region of Hassi Messaoud, which is well known for its petroleum operations, deals mainly with different mechanical sandstone properties and their varying strengths.

The relationships between different depths and both of the mechanical sandstone properties were evaluated. As a result, useful relationships were found for different depths and the following properties: uniaxial compressive and triaxial test, Young's modulus and Poisson ratio.
\end{abstract}

keywords: strength, sandstone, drilling, behavior, rock testing.

\section{Introduction}

The first phase of study considered is the choice of a reference material on which to base the research. This decision must take into account several factors. First of all, the material selected should be representative of materials that will be encountered in the future application of the well drilling. They are highly important for mechanical modelling of hydraulic fractures from drilling, borehole stability and subsidence analyses. Secondly, availability and cost of the material are important aspects to take into consideration when performing the experimental tests. Thirdly, that it be commonly used in that field of interest, so that data and previously obtained results can be found in literature. Sandstone satisfies the first and third requirement.

Sandstone is also important as reservoirs for oil and gas. Sandstones are also important as aquifers for the production of water. Rock often has mechanical prop- erties depending upon the state of stress, lithology, the presence of discontinuities, scale factors and the degree of alteration. As such, the data must reflect not only the mechanical behavior of the intact rock but also the behavior of the rock mass. Instability analysis, the shear strength of the weakest planes is the most important strength parameter.

The drilling of a petroleum well in earth material, these days involves heavy machinery, equipment and tools. The designs of that equipment are carried out to match the strength parameter of the rock mass that the tool is expected to deal with. The characteristics of rock mass vary widely both at local and regional levels.

Herein, a review of rock strength knowledge with particular reference to the resistance of a comprehensive list of known tests has been established.

The descriptions include how these strength property tests were carried out on sandstone samples taken from Hassi Messaoud Well. There is a description of the site geology, the horizon from where the sample was obtained. The laboratory procedures for preparing cores from samples are fully detailed and discussed. The knowledge of the strength of sandstone is important. There are many experimental studies investigating the strength behavior of sandstone (Sheng-Qi et al. 2011; Jerzy 2015; Ngueyep et al 2014; A. Taheri et al 2016; Wong et al. 1997; Wu et al.2000; Klein et al. 2001; Baud et al.2000; Besuelle et al.2000; Tembe et al. 2008; Tsai et al.2008; Huang et al. 2010; Yang and Jiang 2010; and Yang et al. 2011).

The principal goal of this study is to investigate the behavior of sandstone under stress and the relationship between five different depths from $4990 \mathrm{~m}$ to $5015 \mathrm{~m}$ and certain strength properties such as, uniaxial compressive and triaxial tests, the Young's modulus and the Poisson's Ratio. 


\section{Site and sample details}

The Hassi Messaoud (HMD) structure lies approximately $800-\mathrm{km}$ southeast of Algiers, Algeria (Fig.1). It is a flattened, broad, oval anticline trending north- northeast to south- southwest, parallel to the major fault zone. It covers almost 2,000 $\mathrm{Km}^{2}$

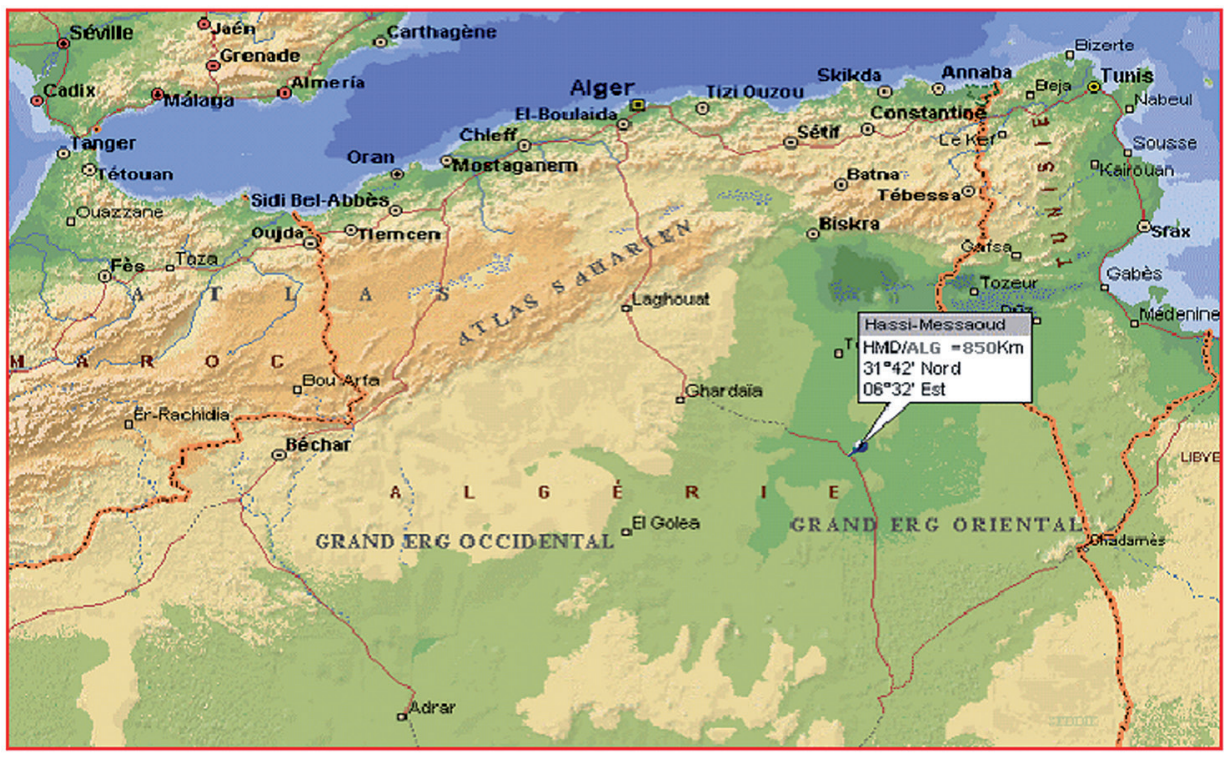

A plug of sandstone was obtained from an exploratory well at the Hassi Messaoud field, Algeria). Litho logically the rock is red, medium-grained, weakly

\begin{tabular}{c|c|c|c} 
Size name & $\Phi(\mathbf{m m})$ & weight \% & cumulative weight \% \\
\hline Coarse sand & 1.5 & 0.44 & 0.44 \\
\hline Medium sand & 2 & 7.25 & 7.69 \\
\hline Fine sand & 3 & 75.16 & 82.85 \\
\hline Very fine sand & 4 & 10.99 & 93.84 \\
\hline Silt and clay size & & 6.16 & 100.00 \\
\hline
\end{tabular}

The cumulative weight (\%) has been plotted against the grain size

( $\Phi \mathrm{mm})$ in Figure 3 and shows the average fine grain size.

\begin{tabular}{c|c} 
Composition & Percentage \% \\
\hline Quartz (including overgrowth) & $80 \%$ \\
\hline Mica (Biotite and muscovite) & $5 \%$ \\
\hline Feldspars & $2 \%$ \\
\hline Chert fragments & $1 \%$ \\
\hline Opaque minerals & $1 \%$ \\
\hline Pyroxene, zircon and other accessory minerals & $1 \%$ \\
\hline Matrix & $3 \%$ \\
\hline Chert & $4 \%$ \\
\hline Clay minerals & $3 \%$ \\
\hline Sera cite & Well sorted sand \\
\hline Sorting & Ranging between 22.00\% and 22.64\% \\
\hline Porosity & With an average of 22.23\% \\
\hline
\end{tabular}

in the Oued Mya basin. The first well, MD1 was drilled in 1956 and more than 1,000 wells have been drilled over the last 40 years.
Figure 1

Hassi Messaoud field location map, Algeria.

microscopy results of the sandstone are shown in Figure 2. Analysis determined the particle size distribution. They are listed below in the Table 1 .
Table 1

Grain size analysis.
Table 2

Mineral composition. 
Figure 2 Optical microscopy of sandstone.

Figure 3 Curve cumulative weight vs grain size.

\section{Preparation of specimens}

A diamond impregnated coring barrel was fitted to the drilling and coring machine to produce cylindrical core specimens. For the test, water was used as a cooling agent during the course of coring. Core specimens were extracted from the plug mutually perpendicular to

Figure 4 Specimens of $25.54 \mathrm{~mm}$ in diameter obtained from original plug $152.4 \mathrm{~mm}$.

\subsection{Testing equipment and procedure}

A cell triaxial rock was used throughout this research to carry out all triaxial compression and uniaxial compression tests on prepared specimens. This machine is automatic, controls the post rupture of specimens, has a capacity of $1000 \mathrm{KN}$ and is capable
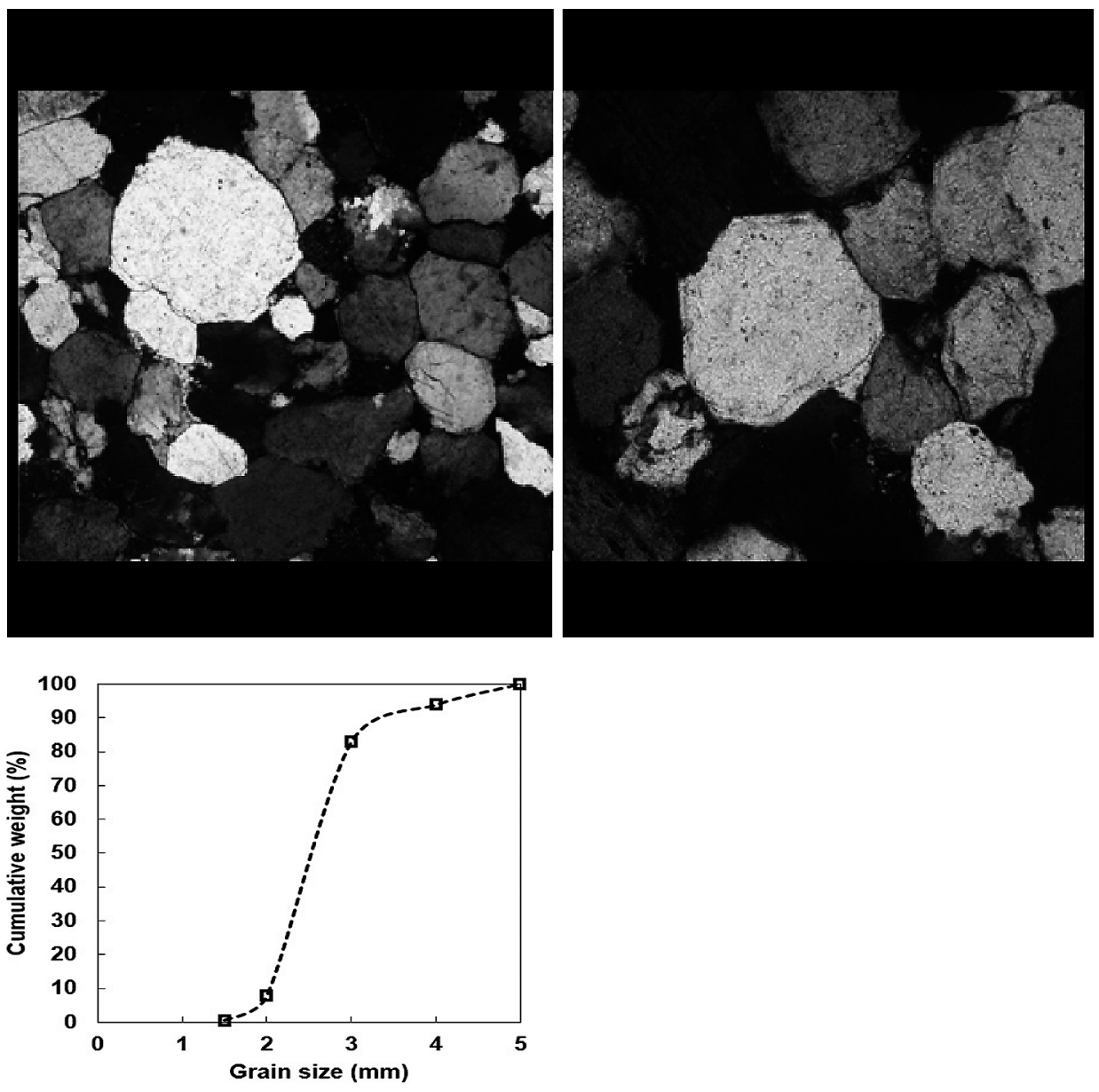

each other.

To ensure that the specimens are right angled, brass cones with internal diameters equal to $25.4 \mathrm{~mm}$ were used during grinding.

The other specimens were prepared according to the ISRM (1981) recommen-

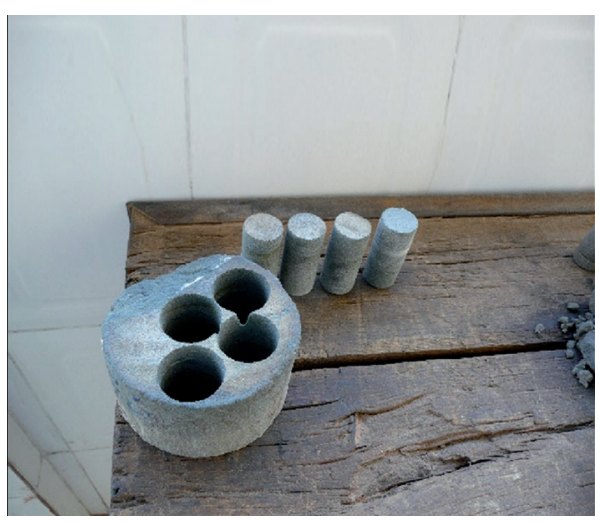

of controlling any test in three modes: load, displacement and strain. During the triaxial and uniaxial tests, the axial deformation was measured using an axial Linear Variable Differential Transducer (LVDT) and the circumferential deformation with an LVDT dations. The original core length of $20 \mathrm{~m}$ from which the specimens were prepared had a $25.4 \mathrm{~mm}$ nominal diameter. The core ends were ground flat and parallel (see Fig.4). The diameter and length of each specimen were measured with a vernier to the nearest $0.01 \mathrm{~mm}$. 

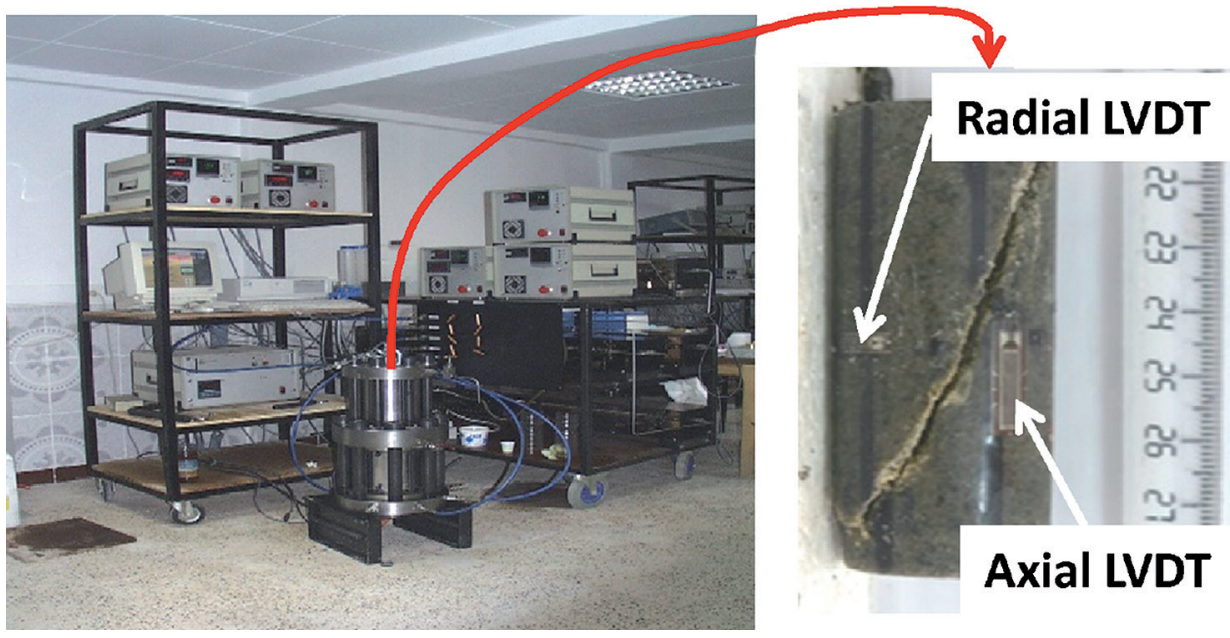

\subsection{Testing Procedure}

All the tests were conducted by using rock mechanics laboratory equipment of the Sonatrach Research and Development center (CRD / SH), with the collaboration of mineral processing and environmental laboratory at Annaba university, mining department (LAVMINE).

All the triaxial tests were carried out at confining pressures of 0 and 40MPa. Each specimen was placed inside the triaxial cell and the cell was mounted between the platens of the

\section{Results and discusions}

\subsection{Hydrostatic compression tests}

In order to identify the anisotropic behavior of the sandstone, hydrostatic compression tests are generally used. Such tests are ideally conducted on cylindrical samples, allowing the determination of three principal strains regarding the structural framework of rock. However, testing machine. The desired confining pressure $\sigma_{3}$ was applied on the surface of the specimen with a hand-pump. The axial stress was applied via a ram passing through a bush in the top of the loading frame.

Axial deformation of the specimens was monitored by an LVDT which was mounted outside the triaxial cell. The strains of the specimens were monitored by the change in amount of confined volume of oil in the triaxial
Figure 5

Triaxial rock mechanics experimental system and strain measurement located in the central part of the specimen.

cell which was automatically recorded. Since the volume of oil in the cell is being kept at constant pressure using the available machine, the volume of oil must adjust to compensate the lateral expansion of the specimen. The principal measurements of the axial stress, axial strain, volumetric strain were recorded by the microcomputer connected to the testing machine. The output data were processed by computer with the aid of the rock mechanics software. for the sake of simplicity, only cylindrical samples drilled in the perpendicular orientation were tested. Therefore, the axial strain indicates the deformation in the direction perpendicular to the bedding planes. The evolutions of axial and radial strains are shown in Fig.6 for five values

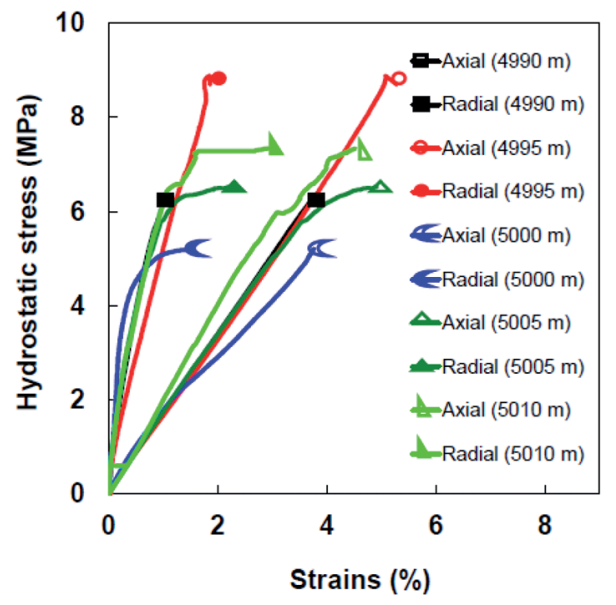

of depth. Observe that the axial strains are much greater than the radial strain for all values of depth which have the same behavior (deformation). This result shows that the sandstone present strains with isotropic deformation properties, Figure 6.

Figure 6

Axial and radial strains during hydrostatic compression tests with different Depth.

\subsection{Uniaxial and triaxial compression test}

This series of tests was carried out on 05 specimens at different depths $(4990 \mathrm{~m}$ to $5010 \mathrm{~m})$. The specimens were prepared in the same manner as those used in the triaxial compression tests. Specimens were dried at room temperature more than two weeks prior to testing and tested in that condition.
Tests were carried out at a strain rate of 10-5s-1, and for each specimen tested, an average value was obtained. The uniaxial compression strength was 
assumed to be the peak point on the stress-strain curve.

Figure 7

Stress-strain curves during uniaxial compression tests with different values of depth.

As in the hydrostatic compression tests, the depth enhances the sandstone differences, particularly in the perpendicular direction see Figure 6.

The results of the experiment presented in Figure 6 show a significant influence of depth on the mechanical behavior of the sandstone. In some cases, the depth leads to strength variation of the sandstone which can be easily observed from data, which show small differences from low confining pressure. Furthermore, in a more classical way, the mechanical behavior of sandstone is affected by confining pressure.

To define the typical stress-strain relationship for rocks, the test is conducted under constant confining pressure pc and a constant axial strain

Figure 8

Stress-strain curves during triaxial compression tests with different values of depth.

Stress-Strain diagrams together with volumetric axial-strain diagrams were plotted for the specimen tests and presented in the diagram of the general behavior of specimens under triaxial compression loading (Fig.10). Table 4 shows the measured peak strength of various tests under confining pressures of 0 and $40 \mathrm{MPa}$ for different depth values.
The results of uniaxial and triaxial tests are shown in the form of stress-

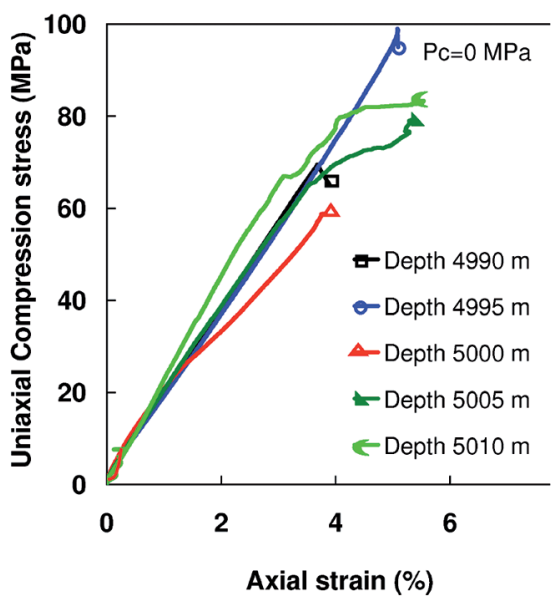

rate. Measurements include the values of axial stress, where in relation to the axial and radial strains, the axial stress is actually the differential $(\mathrm{a}-\mathrm{pc})$.

During the initial stages of loading, the rock stiffens at the beginning point. This nonlinear regime is probably due to the closing of preexisting microcracks pervading in the specimen. This particular region of the stressstrain curve is a signature of the stress history undergone by the rock specimen during past geologic time, including the coring process. As the load increases further, the stress-strain curve becomes linear, wherein this portion of the stress-strain curve demonstrates where the rock behavior is nearly elastic. If unloading occurs in this region, the

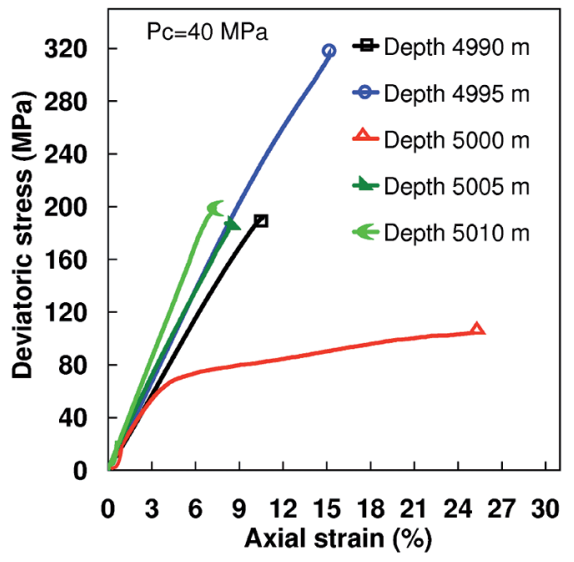

The volumetric strain is defined as the change in volume with respect to the original specimen volume.

For a triaxial test, the volumetric strain of cylindrical specimen is $\varepsilon a+2 \varepsilon r$, where $\varepsilon a$ is the axial strain and $\varepsilon r$ is radial strain.

As shown in Figures 9 and 10, the volumetric strain versus axial stress can strain curves. As given in Tables 3, 4 and Figures 7, 8.

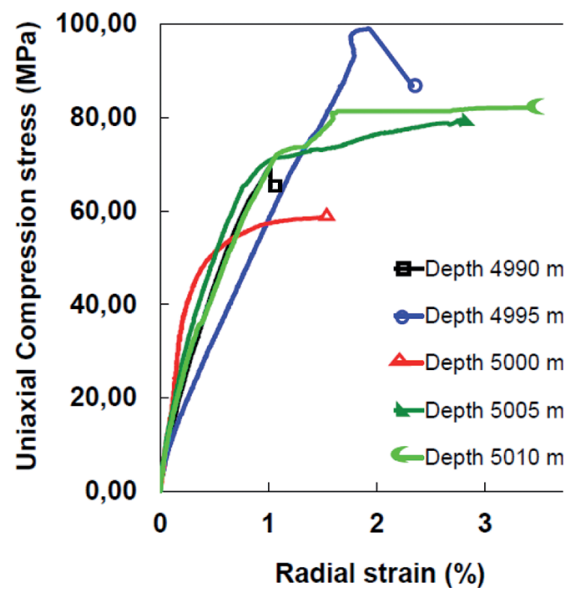

strain returns almost to zero, usually along a different path. This effect is called hysteresis and indicates that some energy dissipates during a cycle of loading and unloading.

When the rock specimen is loaded beyond the point where the rock behavior is nearly elastic, irreversible damage sets in. It is shown by a decrease of the slope of the stress versus radial strain curve (fig 7 and 8). At this stage, the damage is not seen on the axial strain. Beyond, the axial strain also becomes nonlinear, and large deformations eventually occur. If the rock is unloaded in this region, permanent strains at zero stress are observed. Final stage is the maximum load that the rock can sustain under a given confining pressure.

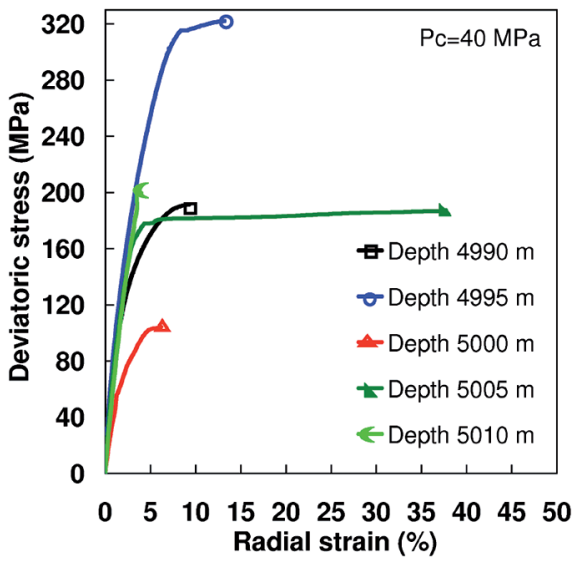

reverse its trend upon reaching a peak after that axial stress increases with decreasing volumetric strain.

The dilatation is responsible for the nonlinearity that is observed in the radial strain and consequently in the variation of volume. This is due either to the creation of tensile cracks that propagate in a direction parallel to the axis of loading 
as shown in Fig.11 or to frictional sliding along rough surfaces and grains. Soft rocks under confining pressure could show a decrease in volume instead of an increase because of compaction. This is typical of mid-sandstones. Compaction in cohesive rocks requires the destruction of cohesion, which could create a sanding problem during production.
Finally, if the framework of elastoplasticity is used, the peak of radial strain is the initial yield point. If the nonelastic component of the variation of volume is negative, the rock is dilatant; otherwise, the rock is compactant. Brittle rocks and ductile rocks must also be differentiated. Brittle rocks are characterized by failure prior to large
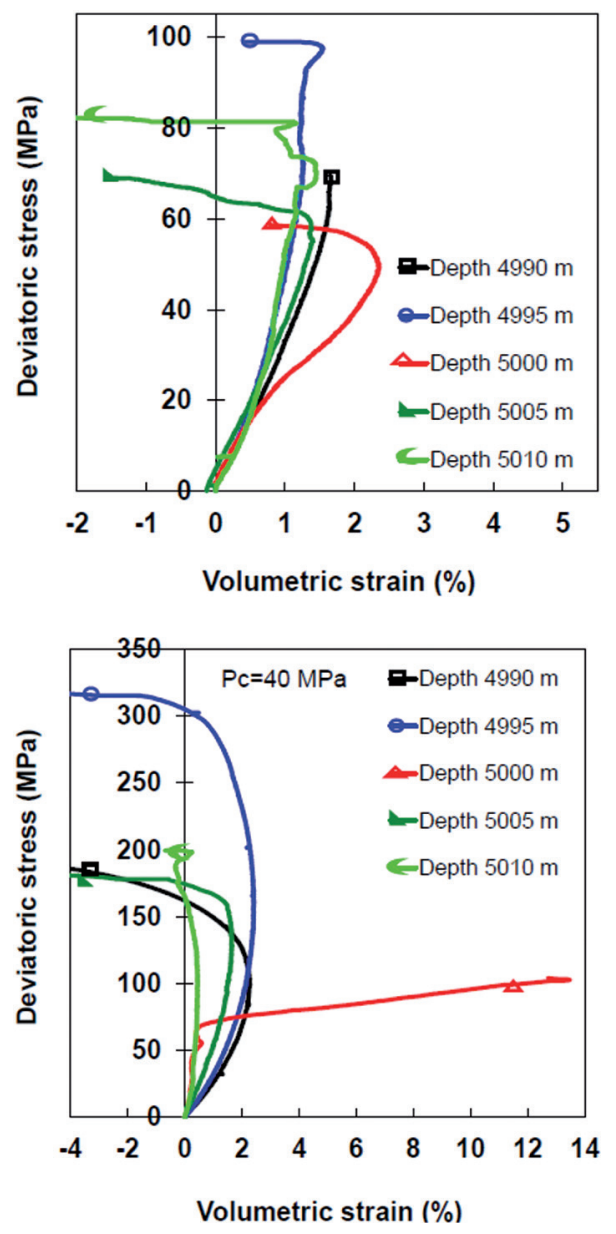

non-elastic deformation, as seen in Figures 7 and 8 .

These behaviors, however, are functions not only of rock type but also of confining pressure, loading rate and depth, with a general transition from brittle to ductile behavior with an increase in confining pressure, increase in depth and decrease in loading rate.

Figure 9

Volumetric strains

during uniaxial compression

tests with different values of depth.

Figure 10

Volumetric strains

during triaxial compression

tests with different values of depth.

\section{Failure mechanism of the tested rock specimens}

Damage mechanism has always been an interesting topic to figure out how solid materials fail by fracturing and cracking. Identifying crack development through laboratory tests would improve our understanding of the real failure process in practice (Geranmayeh et al.
2018,Yang et al. 2015, Youn et al 2010, Eberhardt, 1998.).

The failure modes of the tested sandstone are presented in Fig. 11. This figure demonstrates the crack that generated the failure of the specimen; in all the cases, the failure is produced by shearing and

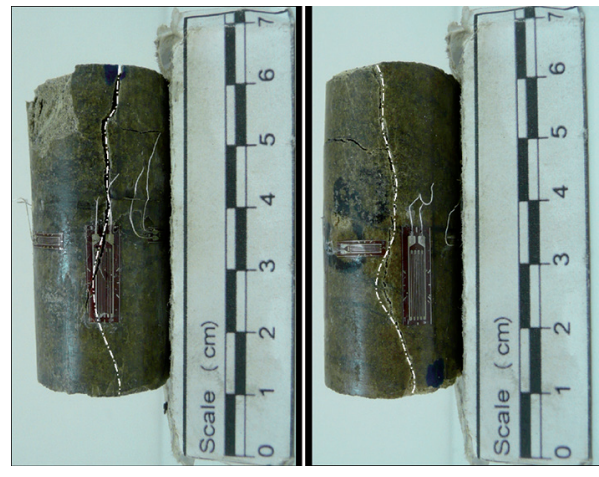

the failure crack has a specific inclination, with respect to the axis of the specimen, which depends on the confinement pressure. The observed failure patterns of the specimens revealed that all specimen failures followed the same mechanism.

Figure 11

Appearance of specimens after testing. 


\section{Effects of depth on the strength properties}

In this research, we study the effect of depth on the strength properties from the uniaxial compressive and triaxial tests. The Young's modulus and Poisson Ratio have been plotted against each other and the results are shown in different tables and Figures 12, 13 and 14.

From statistical analyses, there is no correlation that can be seen in the figures, and this can be explained by the fact that there is sandstone heterogeneity

Figure 12 Maximal Stress variations vs depth.

Figure 13 Poisson variations vs depth.

Figure 14 Elastic modulus variations vs depth. and occurrence of clay with reference to sample $5000 \mathrm{~m}$.

The variation in the strength of these rocks can be easily observed from the data of the UCS and triaxail test given in Tables 3 and 4. Figure 12 shows a plot of UCS and triaxial data versus depth. The UCS data is scattered between 58.83 and 98.98 Mpa.

The maximum stress of triaxial strength increases from 191.57 Mpa for
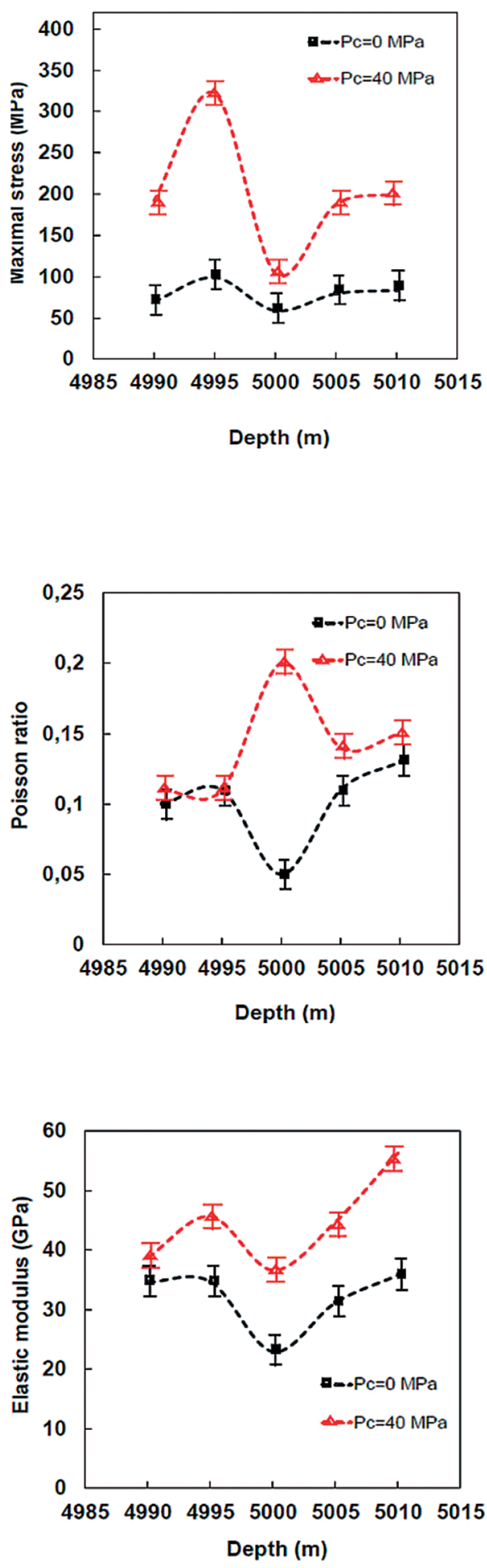

depths of $4990 \mathrm{~m}$ to $321.99 \mathrm{Mpa}$ at a depth of 4995 and decreases from $321.99 \mathrm{Mpa}$ to 104.28 for a depth of $5000 \mathrm{~m}$. This is caused by the non-homogeneity of the specimens, which exhibit a high clay content illustrated in Figure 12.

Poisson's ratio increased from 0.11 to 0.2 for depths of 4990 to 4995 and decreased from 0.2 to 0.14 for depths of $5000 \mathrm{~m}$ to $5005 \mathrm{~m}$. This is caused by the presence of clay in the sample, Figure 13. 


\begin{tabular}{|c|c|c|c|c|c|c|}
\hline \multirow[b]{2}{*}{ Depth (m) } & \multirow{2}{*}{$\begin{array}{c}\text { Peak } \\
\text { Strenth } \\
\text { (MPa) }\end{array}$} & \multirow{2}{*}{$\begin{array}{c}\text { Peak } \\
\text { Elastic } \\
\text { Modulus } \\
(\mathrm{GPa})\end{array}$} & \multirow{2}{*}{$\begin{array}{c}\text { Poisson } \\
\text { ratio }\end{array}$} & \multicolumn{3}{|c|}{ Peak strain (\%) } \\
\hline & & & & $\begin{array}{l}\text { Radial } \\
\text { strain }\end{array}$ & Axial strain & $\begin{array}{l}\text { Volumetric } \\
\text { strain (\%) }\end{array}$ \\
\hline 4990 & 69.52 & 34.61 & 0.1 & 1.02 & 3.67 & 1.63 \\
\hline 4995 & 98.98 & 34.68 & 0.11 & 2.33 & 5.08 & 0.41 \\
\hline 5000 & 58.83 & 22.95 & 0.05 & 1.50 & 3.77 & 0.77 \\
\hline 5005 & 79.34 & 31.16 & 0.11 & 2.77 & 4.00 & -1.54 \\
\hline 5010 & 83.34 & 35.78 & 0.13 & 3.44 & 4.83 & -2.05 \\
\hline \multirow[b]{2}{*}{ Depth (m) } & \multirow[b]{2}{*}{$\begin{array}{c}\text { Peak } \\
\text { Strenth } \\
\text { (MPa) }\end{array}$} & \multirow{2}{*}{$\begin{array}{c}\text { Peak } \\
\text { Elastic } \\
\text { Modulus } \\
(\mathrm{GPa})\end{array}$} & \multirow[b]{2}{*}{$\begin{array}{c}\text { Poisson } \\
\text { ratio }\end{array}$} & \multicolumn{3}{|c|}{ Peak strain (\%) } \\
\hline & & & & $\begin{array}{c}\text { Radial } \\
\text { strain }\end{array}$ & Axial strain & $\begin{array}{l}\text { Volumetric } \\
\text { strain (\%) }\end{array}$ \\
\hline 4990 & 191.57 & 38.76 & 0.11 & 9.27 & 10.57 & -7.97 \\
\hline 4995 & 321.99 & 45.63 & 0.11 & 13.20 & 15.41 & -11.00 \\
\hline 5000 & 104.28 & 36.63 & 0.2 & 6.18 & 25.07 & 12.70 \\
\hline 5005 & 187.47 & 44.73 & 0.14 & 37.98 & 5.96 & -69.99 \\
\hline 5010 & 200.21 & 56.32 & 0.15 & 3.98 & 7.27 & -0.69 \\
\hline
\end{tabular}

There is a general tendency for the elastic modulus and Poisson's ratio to increase with an increasing depth for different values $(5000 \mathrm{~m}$ to $5010 \mathrm{~m})$ indicating
Table 3

Experimental values

of UCS strength for different depth.

Table 4

Experimental values of triaxial strength for different depth.

a definite relationship in the plot shown in Figure 14.

\section{Conclusions}

In this study, the main conclusions, which can be drawn, are as follows:

- It was found that plugs of sandstone rather than cores gave the required physic-mechanical properties and demonstrated the required physico-mechanical properties. This confirms the use of plugs from the core barrel of an exploration borehole as an acceptable practice.

- This study involved: the optical microscopy of sandstone, the particle size distribution analysis, the uniaxial and triaxial compressive strength, stress strain behavior, the Young's modulus, and the Poisson ratio.

- The mechanical properties and failure modes of strength for rock specimens with different depth were studied. The effects of depth on the strength behavior of sandstone have been investigated; the results obtained confirm that the sandstone presents a strong dependency on confining pressure. As a consequence, the Young
Modulus increases (5000m to $5010 \mathrm{~m}$ ) with the increase of depth, while being more sensitive to confining pressure.

- The sandstone failure mode was also influenced by compaction and expansion, leading to a more pronounced transition from brittle to ductile behavior.

It is recommended that field tests be carried out on a sandstone exposure and results matched with that of laboratory tests on a specimen prepared from same exposure.

\section{References}

BAUD P., ZHU W., WONG, T. F. Failure mode and weakening effect of water on sandstone. J. Geophys Res. v. 105, n. B7, p. 16371-16389, 2000.

BESUELLE, P., DESRUES, J., RAYNAUD, S. Experimental characterization of the localisation phenomenon inside a Vosges sandstone a triaxial cell. Int. J. Rock Mech Min. Sci., v. 37, n. 8, p. 1223-1237, 2000.

CIESLIK, Jerzy. Stress drop as a result of splitting, brittle and transitional faulting of rock samples in uniaxial and triaxial compression tests. Studia Geotechnica et Mechanica, v. 37, n. 1, 2015.

EBERHARDT, E., STEAD D., STIMPSON, B., READ, R. S. Identifying crack initiation and propagation thresholds in brittle rock. Canadian Geotechnical Journal, v. 35, n. 2, p. 222 e 233, 1998.

HAWKES, I., MELLOR, M. Uniaxial testing in rock mechanics laboratories. Eng Geol., n. 4, p. 177-285, 1970. In: E. T. (Ed.). International society of rock mechanics, suggested methods, rock characterization testing and monitoring. Oxford: Pergamon Press, 1981.

HUANG, S., XIA, K. W., YANG, F., FENG, X. T. An experimental study of the rate dependence of tensile strength softening of Longyou sandstone. Rock Mech Rock Eng., v. 43, n. 6, p. 677-683, 2010.

KLEIN, E., BAUD, P., REUSCHLE T., WONG, T. F. Mechanical behavior and failure 
mode of Bentheim sandstone under triaxial compression. Phys Chem Earth (A), n. 26, p. 21-25, 2001.

MOGI, K. Some precise measurements of fracture strength of rocks under uniform compressive stress. Rock Mech Eng Geol., n. 4, p. 41-55, 1966.

NGUEYEP, MAMBOU, L. L., NDOP, J., NDJAKA, J.M.B. Theoretical investigations of mechanical properties of sandstone rock specimen at high temperatures. J. Min Sci., n. 50, p. 69, 2014.

SHENG-QI, YANG, HONG-WEN, JING, SHAN-YONG WANG. Experimental investigation on the strength, deformability,failure behavior and acoustic emission locations of red sandstone under triaxial compression. Rock Mech Rock Eng., 2011. DOI 10.1007/s00603-011-0208-8.

TAHERI, A., ROYLE, Z. YANG, Y., ZHAO A. Taheri et al Geomech. Geophys. Geo-energ. Geo-resour. n. 2, p. 1-10, 2016. DOI 10.1007/s40948-015-0017-8.

TEMBE, S., BAUD, P., WONG, T. F. Stress conditions for the propagation of discrete compaction bands in porous sandstone. J . Geophys Res., 2000. Doi:10.1029/2007JB005439.

TSAI, L.S., HSIEH, Y. M., WENG, M. C., HUANG, T. H., JENG, F. S. Timedependent deformation behaviors of weak sandstones. Int. J. Rock Mech Min Sci., v. 45, n. 2, p. 144-154, 2008.

VANEGHI, Geranmayeh, FERDOSI, Behnam, OKOTH, Achola D., KUEK, Barnabas. Strength degradation of sandstone and granodiorite under uniaxial cyclic loading. J. of Rock Mech. Geot Eng. v. 10, p. 117-126, 2018. Issue 1.

WONG, T. F., DAVID, C., ZHU, W. The transition from brittle faulting to cataclastic flow in porous sandstones: mechanical deformation. J. Geophys. Res., v. 102, n. B2, p. 3009-3025, 1997.

WU, X. Y., BAUD, P., WONG, T. F. Micromechanics of compressive failure and spatial evolution of anisotropic damage in Darley Dale sandstone. Int. J. Rock Mech. Min. Sci., v. 37, n. 1/2, p. 143-160, 2000.

YANG, S. Q., JING, H., W. Strength failure and crack coalescence behavior of brittle sandstone samples containing a single fissure under uniaxial compression. Int. J. Fract., v. 168, n. 2, p. 227-250, 2011.

YANG, S., Q., RANJITH, P., G., HUANG, Y., H., YIN, P. F., JING H. W., GUI Y. L., YU, Q., L. Experimental investigation on mechanical damage characteristics of sandstone under triaxial cyclic loading. Geophysical Journal International, v. 201, n. 2, p. 662 e 682, 2015.

YOUN, H., TONON, F. Multi-stage triaxial test on brittle rock. Int. J. Rock Mech. Min. Sci., v. 47, n. 4, p. 678-684, 2010.

Received: 2 August 2018 - Accepted: 14 January 2019. 